\title{
On the Liminal Fertility of Urban Binaries in the Sin City of Neon Lights
}

\author{
ALBERTO DE SALVATIERRA \\ University of Nevada, Las Vegas
}

\author{
SAMANTHA SOLANO \\ University of Nevada, Las Vegas
}

\begin{abstract}
This paper engages in an initial exercise of re-imaging one of the most well-known-and most misperceived-cities on the planet. Las Vegas' one-sided reputation will first be expanded into a series of binary pairings, and then the problematic friction between them will be highlighted. While a structuralist approach, the added dimensionality by these established polarities will reveal the fertile potential of their liminal gradients. As new identities materialize, important questions about the future of Las Vegas will begin to arise. A surprisingly contested and isolated urban condition in perpetual tension between diminishing water resources, vested capital interests, troubled sociological phenomena, expanding military operations, and delimiting natural preservation practices, Las Vegas is volunteered as a city ripe for further critical analysis and exploration.
\end{abstract}

Mocked endlessly as a lascivious fantasy that allows human debauchery to take urban form in the most kitsch of ways, Las Vegas possess a totalizing and singular infamy that has prevented it from joining significant discourse on cities. This conception therefore engenders an attitude that the Sin City's only possible insight to give is that of its own superficiality. Yet, as the city continues to grow-and new challenges like those posed by material flows and climate change become ever more complex-it is time to re-evaluate longheld assumptions about Las Vegas. This paper will therefore engage in an initial exercise of re-imaging one of the most well-known-and most misperceived-cities on the planet. The authors will seek to first expand Las Vegas' one-sided reputation into a series of binary pairings, and then highlight the problematic friction between them. While a structuralist approach, the added dimensionality by these established polarities will reveal the fertile potential of their liminal gradients. As new identities materialize, important questions about the future of Las Vegas will begin to arise. A surprisingly contested and isolated urban condition in perpetual tension between diminishing water resources, vested capital interests, troubled sociological phenomena, expanding military operations, and delimiting natural preservation practices, the authors volunteer Las Vegas as a city ripe for further critical analysis and exploration.

\section{INTRODUCTION}

Learning from Las Vegas could easily be regarded as one of the most significant architectural publications in the last half-century. Excavating an unusual depth from Las Vegas' widely alleged superficiality, it brought attention to a new set of architectural ideologies. However, rather than spurring further investigations into the city, Las Vegas has largely languished in isolation from the discourse: Other than the brave Denise Scott Brown et al, few have returned for serious play at the city of gaming. And, provocative though an exploration of signage and casinos was, what else is there to a consumerist city built on monetizing hedonism, excess and pure id delight? What can be gleaned from yet another sprawling "failed" suburbia in the middle of a barren desert? What can a Disneyland on steroids instruct about city-making and urban life? In fact, perhaps it should come as no surprise Las Vegas elicits such caustic contempt as a site for investigation-let alone speculative and projective exercises from its unique composition.

Or, as any reader might ask themselves: How is Las Vegas relevant? While this is our central question, the departure point begins with the identification of a unique characteristic inherent to Las Vegas: The Sin City of neon lights is an oft-impossible agglomeration of strong and contradictory urban binaries. The scorching heat of an arid city stands in direct contrast to its thirsty lawns and an annual "monsoon" season. The bombastic and flashing façades of the strip are exacerbated by the surrounding "adobe" monotony of the suburbs. As the marriage capital of the world, it lies within the only American state that sanctions prostitution. Even the immediate vicinity of Las Vegas is a contradiction between the destructive tendencies of its military bases with legacies of nuclear detonations and the preservationist attitude of its wildlife reserves. The sacred and the profane coexist in a manner unlike any other American city: Is it Valhalla or Sodom and Gomorrah? It is these liminal conditions in between that both reveal an epistemic fertility that clamors for further study and reflect back the whole of American civilization on itself.

Of course, binaries can be problematic. They are often reductive and frequently perpetuate Western power structures that favor a white patriarchy: man/woman, white/black, rich/ poor. As such, everything outside of those polarities becomes either erased or subsumed, and the resulting framed argument is given heightened authority: good v. bad, what else is left to consider? We agree such a view of the world can be reductive and as post-structuralists might argue, such rigid dichotomies are often too deterministic; reality is that of emergent gradients. ${ }^{1}$ Similarly, we find the interstitial indeterminacy fruitful. However, to arrive at a deeper reality than most afford the "Silver City," we start with certain 


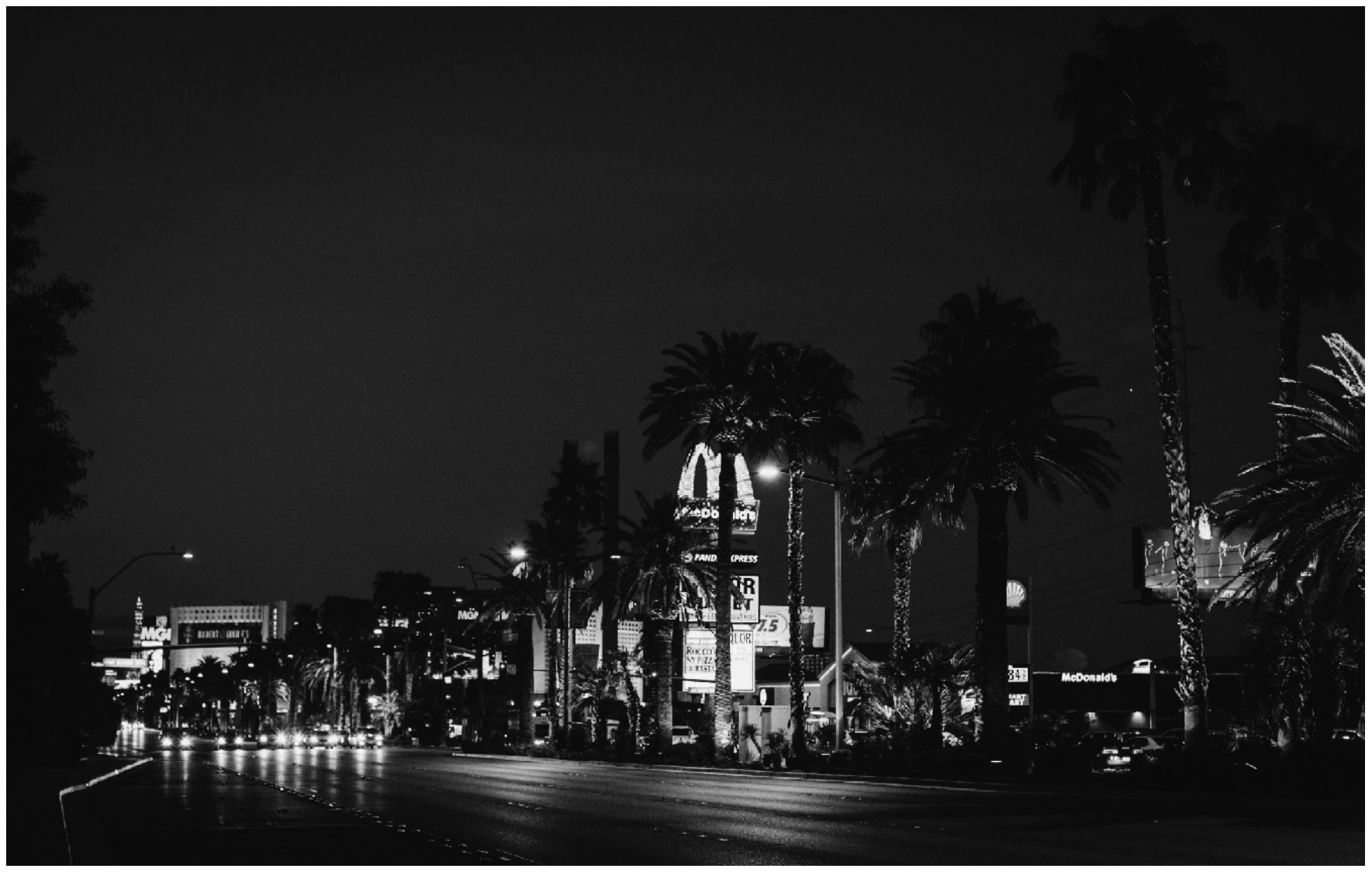

Figure 1: View from South Las Vegas Boulevard toward the Strip; 2018. Courtesy of Michael Raspuzzi.

dialectics - decoupling what is often seen as just a one-sided fantasia-and end with projective speculations about the liminal gradients that ultimately manifest in the in-between.

\section{DRY MATTER. WET MATTER.}

If one knew nothing about geography and landed right in the middle of the Las Vegas Strip, one might be hard-pressed to realize the immediate environment is a rain-shadowed basin in the driest desert of North America. ${ }^{2}$ Ubiquitous lush palm trees (and other vegetation) and an obscene amount of beautiful water features (the record-breaking The Fountains of Bellagio notwithstanding) suggest a beachy semi-tropical utopia instead. Or, if one did have greater awareness of the desert metropolis, knowledge of the 58 golf courses that mottle its urban fabric ${ }^{3}$ (the third most of any city in the United States) or the ever-expansionist verdant suburbs that continuously grow in all directions might make one wonder: How is this possible? Or, better yet: Are these conditions sustainable? Of course, the massive maintenance of grass lawns at both the entertainment or domestic scale is not ecologically-friendly, and the various water features are not resource conscious. Even the suburbs themselves are problematic: as some have pointed out, Las Vegas' “...image of hedonism in the casinos and the good life in gated communities has ravaged the natural environment and emphasized the most narcissistic aspects of the American Dream." ${ }^{4}$ However, the culprit lies not just with a few actors, but with the city itself. As our colleague William J. Smith, here at the University of Nevada, Las Vegas, and Ahmad Safi write, "...the image of the fountains and its surroundings are in direct contradiction to the 'real' Las Vegas. Las Vegas is not a wet, lush place full of elite. However, its population participates in the charade because it is vital to the economy." ${ }^{5}$ And certainly, it is this economic "reasoning" that acts as an obfuscating fog to present and future water resource issues:

Las Vegas has also run headlong into a sustainability dilemma that many in the city appear to find sacrilege to acknowledge. Growth is assumed to be positive at any rate possible. No local high-profile party has a vested interest in any other policy, and the federal government considers growth to be a local matter. Thus, what is on the table instead, is simply how to obtain more resources (i.e. water) to make unlimited growth possible. Ideas on the table for the Southern Nevada Water Authority (SNWA) include bringing water from as far away as the middle of the U.S. from the Mississippi River, cloud seeding which has already been tested towards the top of the country in Wyoming to obtain credits, and desalination of ocean water pumped far up the Lower Colorado River Basin from Mexico... 


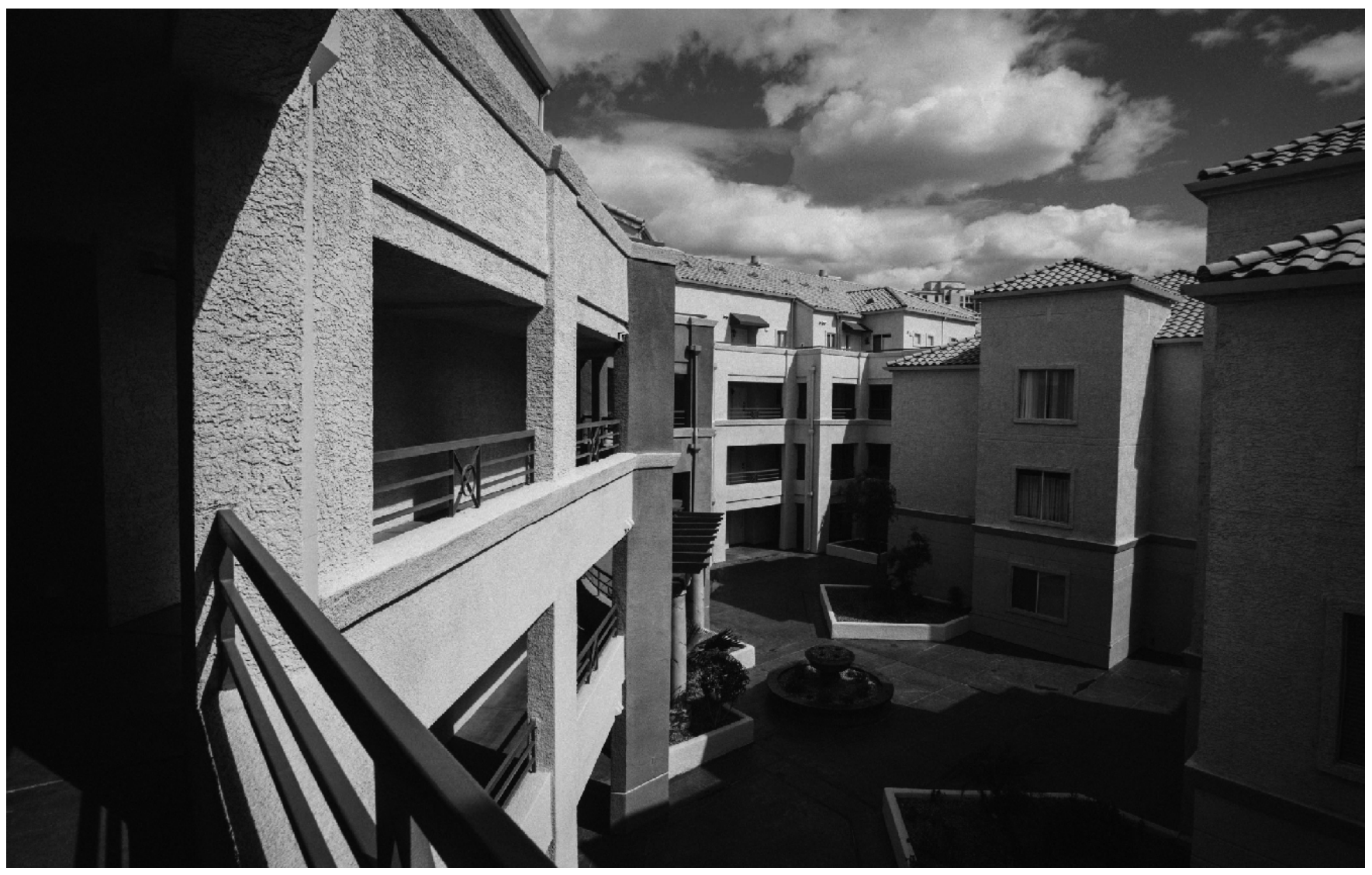

Figure 2: Interior courtyard of a private, and gated, apartment complex; 2018. Courtesy of Michael Raspuzzi.

In other words, Las Vegas is in a state of denial over its arid milieu. The conservationist attitudes more appropriate for "desert living" stand in direction opposition to the capitalist model of continuous growth. Yet, without constant growth, under current operating procedures, Las Vegas would languish. Paradoxically, its thriving is built on dying-but for how long? And now that the springs that attracted early settlers were pumped to extinction and the meadows which give Las Vegas its name were paved over, new paradigms must emerge and new procedures for the city must be formulated. For example, a problem that might surprise outsiders is that Las Vegas experiences drastic seasonal flooding. And until recently, rainwater collection systems in the entire state of Nevada were prohibited. Even a bucket on a porch was illegal. And while on a state-wide basis the recharging of the aquifers is important, urban Las Vegas-where the majority of the city is covered in impermeable surfaces-demands a more complex solution.

Moreover, Las Vegas' problematic relationship with its desert identity and its water resources also stem from a larger discourse (or lack thereof). In landscape architecture, for instance, the climate change conversation is primarily focused on endangered coastal territories due to rising sea levels. This is both timely and appropriate. However, other scenarios-dry ones-which equally require attention are constantly overlooked. This lack of urgency and consideration can be attributed to such designations of arid regions as "barren," "deforested," "overgrazed lands with little value," and "aberrations that need to be repaired and improved" which was embodied by the 1994 UN Convention to Combat Desertification (UNNCD). ${ }^{7}$ Classified arid landscapes account for more than one third of the Earth's total surface and are anything but "barren." They are rich with urban life, provide agricultural necessities, and offer biological diversity-thus reinforcing their need to also be critically evaluated. ${ }^{8}$

\section{STARDUST AND SAWDUST; OR, THE STRIP AND THE \\ SUBURBS}

The dry-wet gradient is not the only one that easily comes to mind when describing Las Vegas. The globally-recognized 'Strip' stands in literal contrast to the suburbs that surround it-differences that can be seen in aerial photography, from space. According to the Las Vegas Convention and Visitors Authority, 42.9 million tourists visited Las Vegas in 2016surpassed in the U.S. only by Orlando, FL. ${ }^{9}$ This means, on average, per month, Las Vegas hosts almost double its population in tourists - and their activities are largely contained to the Strip. Yet, it is not only tourists who prefer isolation. According to Elena Vesselinov and Renaud Le Goix, $70 \%$ of homeowners live in a gated community. ${ }^{10}$ Beyond the service workers, or valets at the perimeters of the hotel-casinos, 


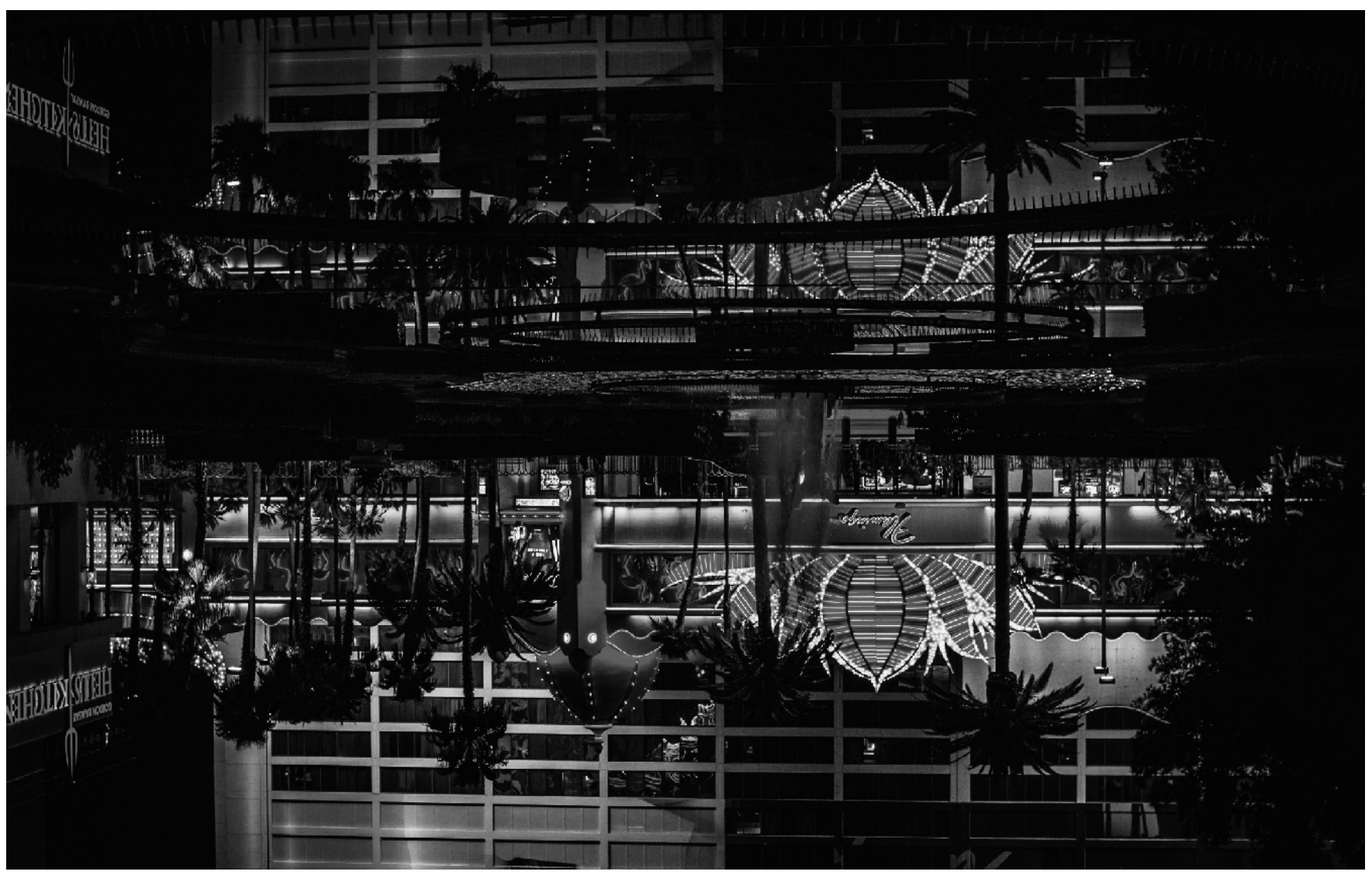

Figure 3: Is it Valhalla or Sodom and Gomorrah? 2018. Courtesy of Michael Raspuzzi.

residents and tourists rarely interact. But surely residents visit the Strip too? It would seem not. Most find such forays into the heart of their city too cumbersome and traffic-ridden to warrant repeat visits. Tragically, it is this separation between the suburbs and the strip that has furthered the impression nothing exists beyond the gilded palaces and exotic temples to capitalism. The ceremonial drama of winning and losing has incorrectly mythologized the city. ${ }^{11}$ To visitors, to Hollywood, and to the rest of the planet, only the Las Vegas Strip exists, and "this malleability of imagery and identity has positioned Las Vegas as a target for critics who see the city as only the Strip and, therefore, as a bastion of postmodern hyper-reality and inauthenticity." ${ }^{12} \mathrm{Or}$, in the words of the very colorful author and critic James Howard Kunstler, Las Vegas is, "a utopia of clowns." ${ }^{13}$ Moreover, "Las Vegas has nearly always been viewed not as an urban place but as an isolated attraction."14 But, beyond the overstimulating kaleidoscopic juxtaposition of Ancient Egypt, the Roman Empire, the Caribbean, New York City, Paris, Venice, Monte Carlo, and Avalon-on the Stripand sprawling suburbs with Mediterranean names, ${ }^{15}$ the city has become an ephemeral urban space that cycles itself anew with indiscriminating frequency, where "landscapes, as well as fortunes, are made and unmade overnight." ${ }^{16}$ And it is this collective urban-fabric that actually generates one of the most peculiar city conditions in America. As Sharon Zukin et al acutely observe: "Contemporary cities are no longer built on visible and tangible production, but on money changing hands. Urban design no longer delineates separate zones for work and leisure; all become one in the consumption of an image that is the city's primary product. With these discursive practices, Las Vegas may well be called the typical 'capitalist city.' ${ }^{\prime 17}$ Therefore, what better subject of study than the modern, post-modern and meta-modern condition of a city with planetary recognition that dawned along with the Atomic age to offer a reflection of America?

\section{FOREVER OR FOR NOW}

Sociologically, Las Vegas is also a fascinating subject of study. As one enters it-either from exiting a plane or by driving down the interstate-visitors are immersed in a visual quandary of once-in-a-lifetime activities "offering a chance to shoot a machine gun, go to strip clubs, and tryout for pornographic movies"18 (to name a few). At the same time, each year approximately 81,000 couples journey to Las Vegas to embark on another (they hope) once-in-a-lifetime event: marriage. ${ }^{19}$ These issues of love and sex, whether tempered by romance or dollar bills, are engendered primarily through Las Vegas' unique geography and urban composition. Las Vegas happens to be one of the most geographically-isolated major cities in the continental United States. The closest three cities: Los Angeles, Phoenix and Salt Lake City, lie in three different states at more than 270,300, and 420 miles away, 


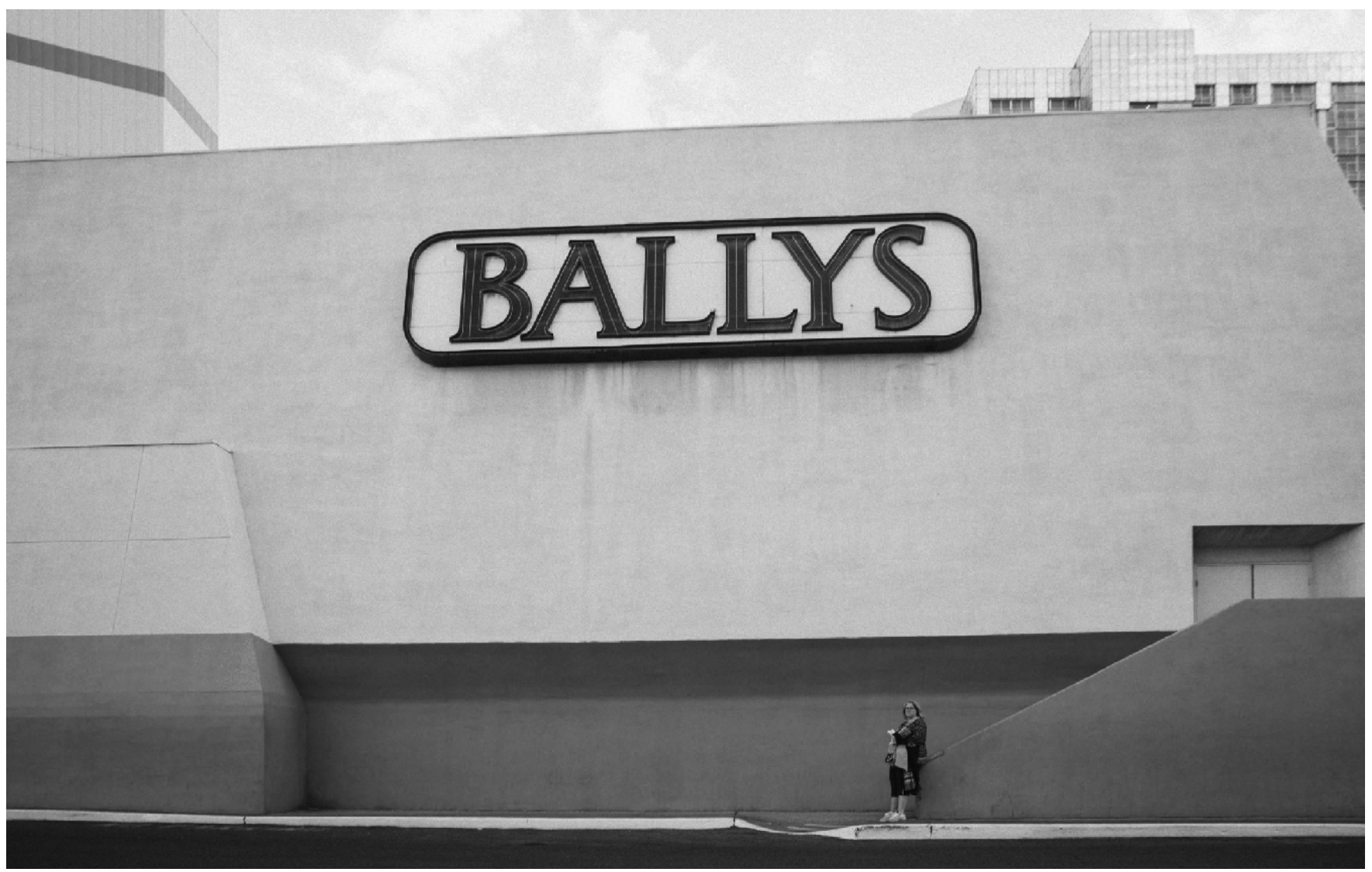

Figure 4: Woman waiting at service entrance; 2018. Courtesy of Michael Raspuzzi.

respectively. Reno, the $2^{\text {nd }}$ largest city in Nevada, is a 7-hour car drive away, or the amount of time it would take to drive the length of Italy from Venice to Naples. This results in Las Vegas' "realistic promise that it can meet most persons hedonistic, if not repressed, desires with enough geographic disconnection ... to keep activities discrete. ${ }^{120}$ At the same time, Las Vegas is such a popular marriage destination because it is built to overwhelm and delight the senses-making 'memorable' easy to achieve. Yet, it owes this to the gaming and entertainment industry, that as many have well documented, ${ }^{21}$ sprung up precisely because Las Vegas was so isolated to begin with. As a resort town, these dialectics are not only interesting, but reveal a set of gradients in between that could redefine understood relationships between sex and the city.

\section{THE DANCE OF LIFE AND DEATH}

More philosophically (or as analyzed from a Freudian lens), Las Vegas is a city of Eros (the 'life' drive) and Thanatos (the 'death' drive) made manifest. The will to live, to create, to produce, and to construct remain in a perpetual tango with the instinct to return to the inorganic in such ways as addiction and the proclivity to numb. At the scale of the ego and the group, Las Vegas' delivery of an experience of abundance reigns supreme. Before arriving, one can select any one of 150,000 hotel rooms across dozens of hotels (Las Vegas is ranked $1^{\text {st }}$ in number of hotel rooms in the United States ${ }^{22}$ ).
Once here, Las Vegas can cater to an obnoxiously wide array of epicurean desires with globally-recognized, endless food offerings as accessible as a buffet or as luxurious as desserts made with gold. And after both proper nourishment and sleep, Las Vegas offers a palette of experiential delights so extensive it has yet to be fully quantified. It is no wonder that many escape the dreadful monotony of the everyday by coming to 'live' here-even if for a short period. However, this excess of 'life' energy is counterbalanced by its opposite. Here, the threshold of addiction-whether gambling, alcohol, sex, tobacco or something else-is easy to cross; many have been lost to the seductive power of the city's dark side. But, Las Vegas operates at many scales, and at the scale of the city, Las Vegas' creative energies are manifested through its constant building frenzy. The most recent statistics state that in $2017,8,411$ new homes were built; 2018 has a forecast of an additional 10,400 new builds. ${ }^{23}$ But of course, Las Vegas was engendered to offer these extravagances of life, again, often by way of its mirror: death. The city demolishes the irrelevant and births new experiences so frequently that "you're adrift in perpetual newness." ${ }^{24}$ The old Vegas - and by old, we mean less than fifty years-is in an on-going jeopardy of full erasure as the value of modern amenity is greater than nostalgia. Because of its age-markedly adolescent compared to other cities - Las Vegas has yet to adopt a conservation mindset. Consequently, the city demonstrates behaviors associated 


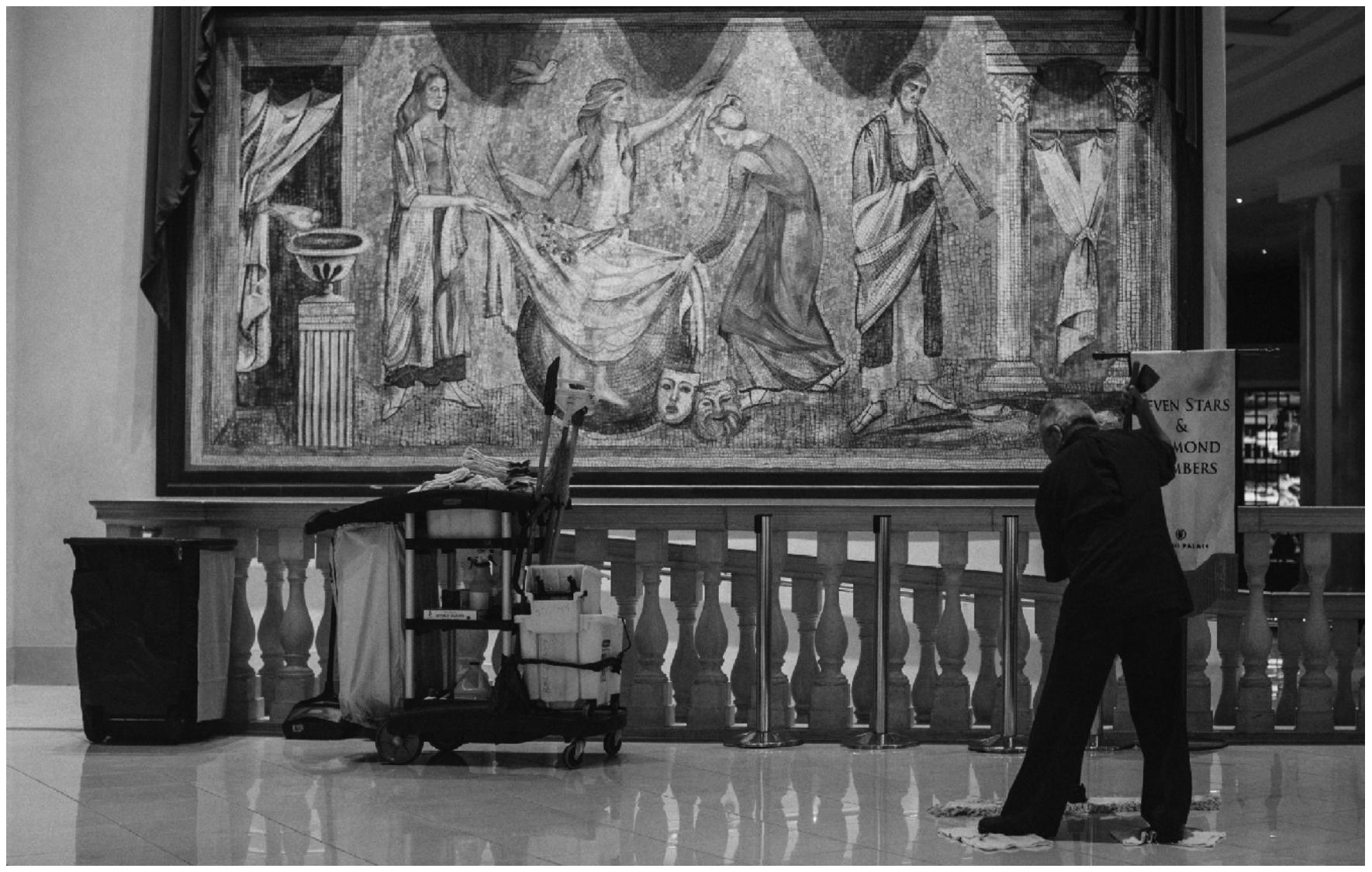

Figure 5: Janitor cleaning in front of a faux-Grecian mosaic of Aphrodite; 2018. Courtesy of Michael Raspuzzi.

with risk, destruction, and narrow-focused innovation. This cycle of creative destruction and destructive creation-this constant desire for novelty-extends beyond the Strip: Subtracting deserts and imploding terrains are common practice in the advent of new development. Absent of limits, development in Las Vegas, is beginning to encroach on conserved Mojave deserts landscapes such as Red Rock Canyon National Conservation Area and the Spring Mountains National Recreation Area.

Beyond city limits, this narrative extends into another extension of the Mojave Desert that has experienced severe mutilations under the pretext of defending (human) life. Up until the Comprehensive Nuclear-Test-Ban Treaty (CTBT), the United States officially conducted 1,054 nuclear test detonations, of which approximately $86 \%$ were located within the former Nevada Test Site (NTS) - now known as the Nevada National Security Site (NNSS). ${ }^{25}$ Concealed between three iconic desert landscapes-Death Valley National Park, the Desert Wildlife Refuge (DWR), and Las Vegas - the NNSS embodies the cultural fetishization that satisfies our curiosity of spectacle, danger, and death. Because of its proximity to Las Vegas, the NNSS' frequent tests (i.e. colorful mushroom clouds) could be experienced from the life, energy and lights of the strip. ${ }^{26}$ As Walter Benjamin famously asserted, "Humankind's self-alienation has reached a point where it can experience its own annihilation as a supreme aesthetic pleasure." ${ }^{27}$ Nevertheless, even though it has been nearly 25 years since the last detonation, the lasting effects and the continued threat of characterizing deserts as empty, lifeless, and prime for destructive alteration remains. The U.S. Air Force seeks to expand the Nevada Test and Training Range (NTTR) into the adjacent DWR which "is the largest wildlife refuge outside of Alaska...and can cover Rhode Island twice-and still have enough room left over for a quarter of a million football fields." ${ }^{28}$ Filled with over 500 plant species and many distinct fauna (e.g., big horn sheep, mountain lions, and 320 bird species), ${ }^{29}$ the DWR offers a unique landscape experience as the Mojave Desert bleeds into the adjacent Great Basin Desert. As the city of Las Vegas continues to sprawl into the Mojave periphery and the NTTR encroaches further into critical desert lands, the need for an understanding of these altered terrains with permeable edges is imperative. Furthermore, within these episodes of the dialectic between life and death, a new reading of Las Vegas can be extracted and expanded-not just about the Strip, but about outlying desert territories as well. And whether through systems thinking or blurred boundaries between conflicting agendas of preservation and destruction, life in the desert city paints a continuum rather than a caricature. 


\section{SACRED VS PROFANE}

In Christian scripture-which has influenced many contemporary Western values and practices-deserts are the place of banishment from paradise. Diane Davis, author of The Arid Lands, points out that "the negative perceptions of deserts that developed during that early period of Christianity, ... those associated with torment and the desert being the result of original sin-were reinforced dramatically during the period of western colonialism and imperialism in the arid lands around the world." ${ }^{30}$ Similarly, David Hickey writes, "to get to Las Vegas, one ascends from Los Angeles, the City of Angels, to the bleak unredeemed Hell of the Nevada desert" where "Las Vegas...is a resort that seeks to recall the frontier West-an egalitarian boomtown in a Biblical wilderness of fallen nature." ${ }^{11}$ Under this interpretation, Las Vegas is an Elysian oasis surrounded by Tartarus; it is a constructed nirvana where "the iconography... is about the validation and celebration of secular ambition" protected from the harsh desert climate. ${ }^{32}$ Conversely, those who regard Las Vegas as an isolated city situated within a vast desert of nothingness might have failed to truly experience its context. If they had, they might realize that the city lies within a diverse landscape of arid beauty, immense topographical monuments, and abundant life. The Southern Paiute-who have occupied this territory long before European conquests - culturally valued and adapted to the desert landscape for its (then) abundant water and food resources. Those open and brave enough to interface with the Mojave Desert find iconic spiritual connections in places such as: Valley of Fire, Death Valley National Park, Red Rock Canyon, Mount Charleston, Joshua Tree National Park, and the like. Under this context, as a disruption of the spiritual and sacred, the "City of Sin" -ironically situated in the unincorporated town of Paradise-lives up to its name, channeling its emblematic aura. ${ }^{33}$ Moreover, since "no one [wants] to give up the fantasy; no one [is] willing to step in and impose regulations on Oz. So, citizens simply [allow] Las Vegas to grow without bounds and without regard to the environment." 34 And, as the Bureau of Land Management (BLM) releases lands to hungry developers for the next set of profits, the city becomes the ravager of a sacred landscapethe disrespectful force of conquest, making it profane.

As a landscape of contested moralities, where do we, as designers, position ourselves? Where do our values lie? Do we consider the city of Las Vegas to be sacred-a city to celebrate for its resilience and ingenuity in thriving within a harsh arid environment? Or, do we emphasize the desertfor its solace, spirituality, and the point of connection to the sacred? The interpretation of a wildlife reserve as sacred and a military base as profane perhaps resonates as true, but is also normative: If these wildlife reserves are furthering problematic conservationist agendas, is their halo removed? Does the NNSS assist in the perpetuity of safety, and therefore life, in America?

\section{FROM DIALECTICS TO GRADIENTS}

The critique of Las Vegas through dialectics opens up the discussion beyond the univocality of The Strip. Previously, most discussions have focused on the negative, the obscene and the caricature of Las Vegas. This narrow focus has limited the potential for analyses of Las Vegas to join multiple conversations about urbanity, the environment, resiliency, innovation, and diversity. This is not to say that the Strip should not be regarded as a topic worthy of study, but moving forward we seek to open the narrative and study the alignments and flows that impact and support this iconic landscape: The good and the beautiful, the bad and the ugly. Additionally, several opportunities for designers to question emerge. How do we design sprawl? How do we preserve old Las Vegas? How do we interface with the desert ecologies? How do we densify and grow with limiting water resources? How do we sustain life with the pressures of uncertain climate futures? How do we see past moralistic judgements of a city? Each of the explored dichotomies - wet vs. dry, stardust vs. sawdust, forever vs. for now, life vs. death, sacred vs. profane-are but a few of the possible filters that allow for interventions at the margins, at the liminal spaces in between. The challenge then becomes, as liminalities blur, to invent new open typologies that invite the rejected into the celebrated and the divine into the obscene. In this nature, Las Vegas is revolutionary as a designer's paradise. Nothing is sacred enough to not touch and nothing is profane enough to not explore. Las Vegas is an open studio where risk is welcomed, global recognition is guaranteed, and innovation is within reach.

\section{ENDNOTES}

1. Michael Merlingen, "Is Poststructuralism a Useful IR Theory? What About Its Relationship to Historical Materialism?" E-International Relations, Last modified May 8, 2013, Accessed January, 2018, http://www.e-ir.info/2013/05/08/ is-poststructuralism-a-useful-ir-theory-and-what-about-its-relationship-tohistorical-materialism/

2. Richard Hereford, Robert $\mathrm{H}$. Webb, and Claire I. Longpre, "Precipitation History of the Mojave Desert Region, 1983-2001," U.S. Geological Survey Fact Sheet 117-03, no.1, Last modified April 4, 2005, https://pubs.usgs.gov/fs/ fs117$03 /$

3. "Las Vegas Golf Courses," Golf Now, Accessed March 27, 2018, http://www. lasvegasgolf.com/courses/.

4. Sharon Zukin et al, "From Coney Island to Las Vegas in the Urban Imaginary," Urban Affairs Review 33, no.5 (May 1, 1998):649, http://dx.doi. org/10.1177/107808749803300502.

5. William J. Smith and Ahmad Safi, "Las Vegas: The Perils of Deception Fueled Growth," Human Geography: A Radical Journal 2, no. 2 (2009): 75, https:// digitalscholarship.unlv.edu/sea_fac_articles/295

6. William J. Smith and Ahmad Safi, "Las Vegas: The Perils of Deception Fueled Growth," 72.

7. Diane Davis, The Arid Lands: History, Power, Knowledge. (Cambridge: The MIT Press, 2016), 3.

8. Danny M. Vaughn, "Arid Climates" in The Encyclopedia of World Climatology, ed. John E. Oliver (Netherlands: Springer, 2005) 86.

9. LVCVA Summary of Monthly Tourism Indicators for Las Vegas, NV: For calender year 2017, Las Vegas Convention and Visitors Authority Research Center, Last modified March 9, 2018, Accessed March 27, 2018, http://www. Ivcra.com/stats-and-facts/visitor-statistics/.

10. Elena Vesselinov and Renaud Le Goix, "From picket fences to iron gates: suburbanization and gated communities in Phoenix, Las Vegas and Seattle,"
GeoJournal 77, no.2 (November 2009): 210, DOI 10.1007/s10708-009-9325-2.

11. Modern Marvels: Las Vegas (The History Channel), directed by Andrew Thomas (1994; USA: A\&E Home Video, 2005), DVD. 
12. Michael Borer, "Re-Sensing Las Vegas: Aesthetic Entrepreneurship and Local Urban Culture," Journal of Urbanism: International Research On Placemaking and Urban Sustainability 10, no.1 (November 2015):114, http://dx.doi.org/10 $.1080 / 17549175.2016 .1139619$.

13. James H. Kunstler, "Las Vegas: Utopia of Clowns from 'The City in Mind'" last modified January 2, 2001. http://kunstler.com/other-stuff/las-vegas-utopiaof-clowns-from-the-city-in-mind/

14. Sharon Zukin et al, "From Coney Island to Las Vegas in the Urban Imaginary," 632.

15. Michael Borer, "Re-Sensing Las Vegas: Aesthetic Entrepreneurship and Local Urban Culture," 112.

16. Mia Gray and James DeFilippis, "Learning from Las Vegas: Unions and Postndustrial Urbanization" Urban Studies 52, no.9 (June 2014): 1683-1684, http://dx.doi.org/10.1177/0042098014536787.

17. Sharon Zukin et al, "From Coney Island to Las Vegas in the Urban Imaginary," 647-648.

18. William J. Smith and Ahmad Safi, "Las Vegas: The Perils of Deception Fueled Growth," 74.

19. Bailey Schulz, "Las Vegas wedding industry wants to boost marriage rate," Las Vegas Review Journal, August 26, 2017, https://www.reviewjournal.com/ business/las-vegas-wedding-industry-wants-to-boost-marriage-rate/.

20. William J. Smith and Ahmad Safi, "Las Vegas: The Perils of Deception Fueled Growth," 71.

21. Stefan Al, The Strip: Las Vegas And The Architecture Of The American Dream. (Cambridge: MIT Press, 2017).

22. Charisse Jones, "Hotel building boom bringing 100,000 new rooms to U.S. cities," USA News, January 10, 2016, https://www.usatoday.com/story/
travel/hotels/2016/01/10/new-hotels-new-york-houston/78422660/.

23. Greg Gross, "Las Vegas Housting 4Q17: With Prices and Production at Record Levels, a Booming Market Shows No Signs of Slowing Down," Metrostudy News, Feburary 4, 2018, http://www.metrostudy.com/las-vegas-housin 4q17-prices-production-record-levels-booming market-shows-no-signsslowing/.

24. Dave Hickey, "Dialectical Utopias: On Sante Fe and Las Vegas," Harvard Design Magazine 4, (Winter 1998): 3

25. "United States Nuclear Tests - July 1945 through September 1992," National Nuclear Security Administration Nevada Field Office, 2015, doi: $10.2172 / 1351809$

26. Sharon Zukin et al, "From Coney Island to Las Vegas in the Urban Imaginary," 649.

27. Walter Benjamin, Hannah Arendt and Harry Zohn, Illuminations. (London: Fontana, 1992), 214-218.

28. "About the Refuge," U.S. Fish and Wildlife Service, Last modified July 22, 2013, https://www.fws.gov/refuge/Desert/about.html

29. U.S. Fish and Wildlife Service, "About the Refuge."

30. Diane Davis, The Arid Lands: History, Power, Knowledge, 20.

31. Dave Hickey, "Dialectical Utopias: On Sante Fe and Las Vegas," 2-3.

32. Dave Hickey, "Dialectical Utopias: On Sante Fe and Las Vegas," 2.

33. William Douglas and Paulina Raento, "The Tradition of Invention: Conceiving Las Vegas," Annals of Tourism Research 31, no.1 (January 2004): 8, http:// Las Vegas," Annals of Tourism Research
dx.doi.org/10.1016/j.annals.2003.05.001

34. Lawrence Herzog, Global Suburbs -Urban Sprawl from the Rio Grande to Rio de Janeiro, (New York: Routledge, 2015), 100. 